\title{
After God: Practical theology as public Christology from the margins of the market
}

\begin{abstract}
Author:
Johann-Albrecht Meylahn ${ }^{1}$

Affiliation:

${ }^{1}$ Department Practical

Theology, Faculty of

Theology, University of

Pretoria, South Africa

Correspondence to:

Johann-Albrecht Meylahn

Email:

johann.meylahn@up.ac.za

Postal address:

PO Box 14885, Lyttelton

0140, South Africa

Dates:

Received: 31 Mar. 2015

Accepted: 10 May 2015

Published: 28 Sept. 2015

How to cite this article: Meylahn, J-A., 2015, 'After God: Practical theology as public Christology from the margins of the market', HTS Teologiese Studies/

Theological Studies 71(3),

Art. \#2975, 9 pages. http://

dx.doi.org $/ 10.4102 /$ hts.

v71i3.2975

\section{Copyright:}

(c) 2015. The Authors.

Licensee: AOSIS

OpenJournals. This work is

licensed under the Creative

Commons Attribution

License.
\end{abstract}

Read online:

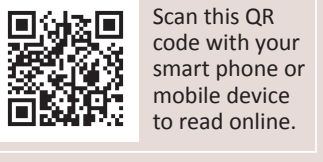

This article is part of a research project, Conversations after God. The focus of this article is to reflect on the theory and methodology of practical theology in a post-metaphysical (After God) context. It will be suggested that practical theology can redefine itself as public theology, but specifically as Christology by engaging the public texts within their contexts, but from a Christ-science hermeneutical approach. The proposed approach is a hermeneutical approach where the Christ-Ereignis guides the inner- and inter-textual reading of texts within contexts. This Christ-Ereignis cannot be translated into a science or even a definable philosophy and therefore the logos is crossed out. Christology, as public theology is done from the margins of the dominant discourses and therefore it could be seen as a Christology from the margins of the market to create spaces of kingdom life: life in fullness.

\section{After God: post-metaphysical God-talk/theology}

In a post-metaphysical context, after the closure of metaphysics, all theologians have are texts and nothing beyond texts within contexts. What is left for theology in a post-metaphysical context? If there is nothing, why then is there a religious turn together with the turn to literature? Would the turn to literature not be enough if all one has are texts, so why is there also a turn to religion or lived spirituality (Van den Hoogen 2013)? In this article I will argue that the turn to literature is enough, but that does not exclude the possibility of God-talk, because what is left for theologians is an intertextual reading of texts from a Christological hermeneutic point of view. In a postmetaphysical context it does not make sense for theology to engage in speculation about the Other, the uncanny, the mysterious, and therefore I will explore a Christological alternative to the mystical turn to religion after the closure of metaphysics, as I believe this is more life-embracing than the various mystical turns.

Post-metaphysical theology can be interpreted as being theological where God revealed in Christ is the hermeneutical centre of the whole theological approach, but without turning towards a speculation about the Other. Christology is the hermeneutical key of all the movements rather than just the traditional normative or prescriptive (historical and systematic theology) movements of the Zusammenshau (Ebeling 1975:164) of the encyclopaedia of theological disciplines. In other words, God, as revealed in Christ, is not only a theme to be reflected on in systematic or historical theology, but becomes a post-metaphysical interpretation of God which informs the methodology of doing theology as such. A post-metaphysical interpretation of God, which can engage public discourses critically and therefore a public theology from the margins, will be developed.

To be able to say this and thereby make such a strong claim, certain things need to be unpacked. Where would such a theology begin? Theology would begin where one always already is, namely within the context of Dasein, that is, not the context in general, but the particular context of a particular Dasein (being-there-in-a-particular-world). The focus is on particular texts ${ }^{1}$ (persons, experiences, practices, actions, phenomena) within their particular infinite chains of texts which form a web of texts, namely a context: archi-writing. Context, understood as that in which text(s) are embedded, and thus the context shapes and co-determines the meaning, value and identity of the texts. Texts find their home (habitus) within a particular web of texts that form the context or the archi-writing of that particular text. A text, on the other hand, is everything that can be identified, named, has meaning and is interpreted and as such it is writing: the construction of meaning through signs. This understanding of text always within context is developed from the linguistic turn, specifically in the thinking of Heidegger (1971) and Derrida (1997). Heidegger refers to language as the house of being ${ }^{2}$. Yet, this house of being is taken for granted and as such it is not noticed, because it is the silent speaking of language that is forgotten or is not heard. 1.In this article I will follow Ricoeur in his use of the word 'text' to refer to the objects of sociological research (Ricoeur 1973:91).

2.'To reflect on language means to reach the speaking of language in such a way that this speaking takes place as that which grants an abode for the being of mortals' (Heidegger 1971:192). 
The speaking of language is not heard and therefore one presumes that one's world is the natural or God-given world (see also Meylahn 2014a:3 of 11). The world as it 'is' for me is not perceived as a social construction, but is perceived rather as the way the world truly is: this is how reality truly is, it is obvious I can see it; I can even touch it! One could say that reality has reached self-consciousness and it appears as truly given as it is. The world is reality and the way things truly are. This is unquestionable, because it is obvious, it is natural or it is God-given, one argues, finding it nearly impossible to comprehend that what is, is not 'real', but only my or our particular social construction of what 'is'. The world (my perception of reality) is not obvious, natural or God-given, but is a product of my social construction. It is my or our particular house of being, that is the particular language of my and our Dasein. Heidegger referred to this as the silent speaking of language. Silent, because it is not heard and even less noticed, therefore one is not aware that my house of being (my world) is the silent speaking of my language ${ }^{3}$ and not reality-in-itself.

This silent speaking of language, of which one is not aware, creates one's world and gives a specific place and identity to each thing within that particular world. Therefore one is not necessarily aware that the various texts (actions, experiences, phenomena) are embedded within a particular context (world), but one presumes them to be the way they truly are. One's experience of something is taken to be the way the thing experienced truly is in-itself. One is not aware that it is this particular world (context) that gives these texts meaning, value and identity. The silent speaking of language, taking Heidegger's thinking into consideration, is where things (texts) carry out a world (context), and world (context) grants place to things (texts) (see Heidegger 1971:200). In other words, things (texts) have meaning only because they are embedded (find a home/are given a place) within a particular context (my or our world) and it is therefore this context (my world) that gives them place: meaning and identity ${ }^{4}$.

This mutual carrying out of world and granting place to things is the silent speaking of language in and out of difference (Austrag) (Heidegger 1971:200ff.). This carrying out and granting place happens simultaneously so that world and things mutually presuppose each other. The silent and forgotten speaking of language is all there is. One cannot move outside of the world, as one cannot move outside of the silent speaking of language. There is no God's eye view from outside of context. Any attempt at moving outside would have to take place in language and therefore one can say with Derrida that there is nothing outside text or context (see Derrida 1997:158).

This is where theology always already finds itself in the midst of things: midst of Dasein. Dasein understood as being-there-in-the-world-with-others, with language being the house (home) of this being-in-the-world-with-others.

3.See also Meylahn (2014a), where I have developed a similar argument.

4.I have developed these ideas in other articles, for example see Meylahn (2014a).
Therefore one can argue that one is in language. Language is here understood very broadly as writing or the creation of meaning and sense through signs. Derrida's famous statement that there is no outside text can therefore be understood as that one is within text, and any attempt to get out is only a movement from one sign to another, but never outside the infinite chain of signifiers. This movement creates an infinite chain of texts, and each text is within its particular context of infinite chains of signifiers. These texts within their contexts might inform each other and they might refer to each other, but they never reach that which is beyond text or outside of text. There reference is always other signs and never the Referent outside of signs. Therefore one can agree with Heidegger and Derrida that language is the house of being, language is the habitus of Dasein.

Metaphysics, the discipline that tries to think the beyond (meta) of physics or beyond as in the foundation of 'physical' reality is thus fundamentally wounded by this realisation that there is no way to the beyond (meta). All metaphysical theories are inscribed within text and there is no beyond inscription. This wounding of metaphysics allows one to speak of a post-metaphysical approach. Theo-logy, which is traditionally linked to metaphysics as the logos of God or the Transcendental, is also only one such inscription. Theology understood as an attempt to understand or think or talk (logos) about God (theos) is impossible unless God is interpreted (inscribed) differently (see also Meylahn 2014a:4 of 11).

There is a tradition that has attempted to do just that, think theology differently; this tradition is negative theology. Negative theology realises the impossibility to talk of God and therefore the impossibility of theo-logy. Negative theology is an ancient tradition, and yet Derrida engages with this tradition arguing the close proximity and difference of his understanding of différance to negative theology (see Derrida 1995, 2008 and Meylahn 2013:226ff.). I follow this engagement between différance and negative theology, as I believe that it might open doors to re-thinking theology today.

The impossibility of speaking conclusively of God in the negative theological tradition is similar to the impossibility of speaking conclusively about anything. In the negative theological tradition this impossibility has to do with a characteristic of God and God's relationship to humanity. In différance it has to do with the grammatology of language. If one is always in language, and there is no outside text, then everything is marked by différance. It is this similarity, although also the important difference, that attracts Derrida to the negative theological tradition. It's recognition that it cannot say anything conclusive about God, is true not only for God, but for anything, taking the grammatology of language into consideration. Any attempt at saying (thinking) something about anything is always said (thought) in text, and texts are marked by différance and therefore nothing conclusive can ever be said. Every 
other that one wishes to think about is similar to the God of negative theology and therefore Derrida can say 'every other is wholly other (tout autre est tout autre)' (Derrida 1995:74). One is always already in language and any attempt to go beyond language is impossible. All that one discovers, in any attempt to go beyond language (outside the text), is an infinite referential chain of signifiers. This infinite referential chain can also be referred to as the infinite desertification of language, which Derrida, in reference to the God of negative theology, argues is a good name for saving God (Derrida 1995:56). The desertification of language is not only a good name for God, whereby not only the name of God is saved, but it also keeps God's name safe from idolatry. As God is a name worth saving and by saving it as the name for this infinite desertification, God is saved from the idolatry of the all the names and concepts of God which humans construct (see Derrida 1995) . $^{5}$

Negative theology reveals something of the call inherent in language, namely prayer: the desire to connect to the other in response to the call of the other. Prayer in the negative theological tradition is a way to cross the desert. Prayer was the main characteristic of life in the desert monasteries, as it was the way to cross the abyss, as it is a response to the call of the Other in the address to the Other. This tradition helps one to understand what is happening in language: language understood as an attempt to cross the abyss (the endless desertification of language) in response to the call of an other as an address to an other. Language attempts to cross the desert of infinite chains of signifiers, but never reaches anything but other signifiers. Yet, it does this because of a call by the Other or the call of reality that wants to be named or addressed and in that sense language can be understood as prayer.

Caputo (2006), following Derrida and his conversation with negative theology, attempts to think theology differently (post-metaphysically) and therefore thinks a theology of the event, which is an inner-textual event. Theology, as theology of the event, is something that happens in texts and between texts. Or stated differently it is the prayer in language; the prayer which calls for the coming (arrival) of the other (who never arrives), which is another way of speaking of autodeconstruction: that which breaks texts open for what is always still to come - a certain messianism without messiah (Derrida 2002).

Kearney (2010) Anatheism: Returning to God after God, is another attempt at a post-metaphysical theology, or as a postGod-is-dead possibility of faith through an un-decidable inconclusive openness towards the Other, as the stranger ${ }^{6}$.

The danger in these various forms of post-metaphysical theologies (for example Caputo's and Kearney's) is that différance becomes the last philosophy, as Laruelle accuses Derrida of (see Laruelle 2010). In other words, that this

5.These thoughts are also explored in the following article see Meylahn (2014a).

6.For further or similar exploration of these ideas see, Meylahn (2014b). philosophy of difference or différance argues conclusively of a relationship between text and 'reality' even if that relationship is a non-relationship or the correlation is a correlation of nonrelation relation or a relation of absolute difference.

These different theologies attempting to think God alternatively, either thinking God as event (Caputo 2006), or as the God who may be (Kearney 2001), or God in anatheistic terms (Kearney 2010), are in a sense grounded in a philosophy of difference. This would then still be a construction of the Other, as an attempt to think the Other. Is there another way? I would suggest to move beyond seeking to know God or to know the other who is every other. To accept that one cannot know God conclusively nor not-know him conclusively, as God and reality are indifferent to human knowing or notknowing. Therefore the focus could be on what one does have, and that is text (Derrida 1997:158). Laruelle radicalises this statement of Derrida by arguing that all we have is a vision-in-One (Laruelle 1999, 2003), which is a given withoutgivenness. Theology of the event or theology as anatheism are still texts, constructions and therefore part of a visionin-One. It is this vision-in-One that is the focus of theology as theology focuses on what is at hand (what one has access to): the practices and daily experiences of the Sacred or Other (lived religion), but always expressed in texts (various postmetaphysical theologies or novels or artworks). That is all one has: all there is, is text and no outside text (see Meylahn 2014a:4 of 11).

There are two good theological reasons (Meylahn 2014a:4 of 11) to have this focus on the vision-in-One rather than seeking various theologies or negative theologies of the Other (mysticism, panentheism, anatheism, et cetera). The first is a biblical text that invites believers to have this focus rather than seeking to know the Other, namely John 14:7. The second text is from the protestant tradition, namely Luther who, following Paul with regards to not knowing anything but Christ crucified (1 Cor 2.2), had very strong words for any theologian that sought to seek God outside of Christ crucified $^{7}$.

If God is sought elsewhere than in the cross, that theology becomes a theologia gloriae. Theologia gloriae can be interpreted as religion or as the sacred canopy of our world-creation. In that sense it is an idol, a social (human) construction. Any other theology, but theologia Crucis, is idolatry and therefore the shift from theology to Christology, but where the logos is also crossed out - not erased, but crucified, so as not to become an idolatry in itself. Crossed out (crucified) so as to

\footnotetext{
7.18. It is certain that man must utterly despair of his own ability before he is prepared to receive the grace of Christ. 19. That person does not deserve to be called a theologian who looks upon the »invisible» things of God as though they were clearly "perceptible in those things which have actually happened" ( $\mathrm{Rm}$ 1:20; cf. 1 Cor 1:21-25). 20. He deserves to be called a theologian, however, who comprehends the visible and manifest things of God seen through suffering and the cross. 21. A theology of glory calls evil good and good evil. A theology of the cross cross. 21 . A theology of golly cross calls the thing what it actually is. 22 . That wisdom which sees the invisible things of God in works as perceived by man is completely puffed up, blinded, and hardened. 23. The »law brings the wrath « of God (Rm 4:15), kills, reviles, accuses, judges, and condemns everything that is not in Christ. 24. Yet that wisdom is not of itself evil, nor is the law to be evaded; but without the theology of the cross man misuse the best in the worst manner. 25. He is not righteous who does much, but he who, without work, believes much in Christ (Luther 1518).
} 
not become a way of seeing or thinking or understanding, as that would lead to work-righteousness and vainglory (Meylahn 2014a:5 of 11). A logos would be a workrighteousness and therefore the logos needs to be crucified so as to remain utterly dependent on or re-inscribed in text (scripture), Christ, faith, and grace alone.

Is there a God beyond these human constructions? From the above it is clear that this is not something that one can argue conclusively for or against, as whatever argument one would propose would again only be a text: construction or idol, that is to say, a particular and therefore a context dependent theologia gloriae. It is even still a theologia gloriae if it is a weak theologia gloriae, or an uncertain theology, as in anatheism.

With all three options either a conclusive theism or a conclusive atheism is problematic, but so also a inconclusive uncertainty between the two in the form of anatheism:

One cannot conclusively argue for either atheism or theism, as both are social constructions and in that sense theologia gloriae or a-theologia gloriae, even anatheism as an attempt to move beyond (post) the dualism of theism versus atheism remains a theoogia gloriae. (Meylahn 2014a:4 of 11)

Therefore the focus should rather be with the Vision-in-One ${ }^{8}$ as revealed in the narratives of Christ. Such a focus would be on the incarnation and immanence, rather than on the impossibility or possibility of knowledge of transcendence or the Transcendent. The focus is neither on the Other or Stranger that breaks into texts, or that haunts the texts, as I do not see much sense in such speculations about the other, therefore the focus will rather be on the Other made in human likeness (Phlp 2:5); the Other made text. The focus will be on the text given, the Christ-Ereignis, but interpreted as an inner-textual event. I will therefore rather argue for a Christology or the Christ-Ereignis ${ }^{9}$.

\section{Practical theology as public Christology}

'If one is always already in the text, and therefore theology will always already have started, then the theologian today comes to that which has already begun only to witness the Christ-Ereignis within and between texts in their contexts' (Meylahn 2014a:5 of 11). Yet the only place to 'start' is where one already is, in a particular Dasein. This Dasein which is a Dasein of a particular silent speaking of language within which one seeks to understand texts (experiences, practices, actions) within its infinite referential chain of texts forming the contexts.

If the focus is on the Christ-Ereignis, then the very next question is: which Christ, or whose Christ? There are so many alternatives, even conflicting interpretations of who

8.1 have explored the connection between Laruelle's Vision-in-One and Christ in Meylahn (2014b).

9.I specifically use the German term Ereignis to link it to Heidegger's thinking of the Ereignis as a disclosing appropriation, as Hofstadter (1971:xxi) translates it.
Jesus was or is. The New Testament alone has at least four different and conflicting versions of Jesus. Then there are the different denominational interpretations of Jesus, as well as various other non-Christian interpretations of Jesus. The focus on the Christ-Ereignis is not to focus on the true or correct Jesus. It would be contrary to the argument of this article to even think it would be possible to have a correct and conclusive interpretation of Christ.

To unpack the Christ-Ereignis, instead on focusing on various Christologies or gospel interpretations of Christ, I will take the Carmen Christi (Phlp 2:5-11) as a guide. I make use of the Carmen Christi because it points one in a different direction of understanding Christ as the One. As One who did not seek equality with God, can be understood as he did not seek to be God (the Transcendent), but emptied (kenosis) himself of all divine content (Transcendent content). Thus one has a movement here not from the flesh (text) towards God or Other, but an emptying of God or Other in the flesh (text), therefore one can speak of a radical immanence. If one reads this text together with the above argument, one could say that Christ did not seek to be a true and correct presentation or representation of the Other. He emptied himself of all such ambition to be just that, as there was no content of the Other in him. He was an empty symbol of the Other. Ray Brassier's (2001:273) concept of a radicalhyle in response to Laruelle's non-philosophy is useful in understanding this kenosis, or radical immanence. The radical-hyle 'enacts matter's transcendental foreclosure to thought within thought' (Brassier 2001:10). The radical-hyle enacts the other's foreclosure to thought within thought. A radical-hyle is a non-conceptual symbol, in other words it is not an empirical conceptualisation of matter (the other), nor a transcendental materialisation of the concept (see Brassier 2001:273, see also Meylahn 2014a:5 of 11). If anything it is an axiomatic heresy (see Brassier 2003); an axiomatic heresy that can only be embraced in faith alone as a gift (grace alone), it cannot be argued theorematically or dogmatically; therefore it is without any philosophy of correlation or philosophy of difference (see Laruelle 2010) to substantiate it, and lastly text (inScription) alone as there being nothing outside of text. Jesus, interpreted as radical-hyle, as a non-conceptual symbol, as an axiomatic heresy, can only be embraced in faith and as a gift (given without givenness). It is on the basis of such a post-metaphysical interpretation of Christ, with the metaphors of a radical-hyle and/or axiomatic heresy, that one can speak of a Christology or science of Christ (see Laruelle 2008) as a non-philosophy philosophy or nonreligion religion: a Christology, where the logos has been crossed out, crucified (see Meylahn 2013:318f.).

In the Christ-Ereignis, as it is described in the Carmen Christi, one can identify three movements (incarnation - crucifixion resurrection and ascension), that make up the Christ-Ereignis. In a sense one can say that the Christ-Ereignis cannot be thought if these three movements are not considered. In this article the three movements will be read in conjunction with the five dance movements developed in Church emerging from 
the cracks (Meylahn 2012:53ff.) as part of an attempt to think a post-metaphysical public Christology.

Theology, at least public or contextual theology, begins with the context. The task of theology is to interpret what is happening in the context in the light of Scripture. In the context of the argument of this article, one needs to add that the context is not just interpreted in the light of Scripture; the various texts (experiences, actions, practices, politics) of the context need to be interpreted within their contexts (archiwriting) as the silent speaking of language of a particular Dasein.

For a theologian the context is read both in the light of Scripture as well as in the light of the silent speaking of language. What does in the light of Scripture mean? I would suggest that it could mean, following the challenge of Philippians 2:5, to have the same mind as Christ. The public theologian, having the same mind as Christ, follows Christ into the context in a spirit of imitatio Christi. Imitating Christ cannot mean taking a particular interpretation of Jesus into account and following that, because which interpretation of Jesus would one imitate? The imitatio Christi is imitating the three movements of Christ, rather than specific content of his teaching or actions (miracles). The first movement is incarnation, as already discussed this is an emptying of all divine content (content of the Other). Theologians, not seeking God, do not seek the final and conclusive truth of the context, because all they will find is their own truth reflected back to them. Rather they seek to understand and read the context in the light of the silent speaking of language, in other words, how these texts in context are unconcealed to them (received in their context) in a realm of the concealment (the silent speaking of the language of the context) and of their concealment (the silent speaking of their language) (see also Meylahn 2014a:5 of 11).

In following Christ, the theologian finds herself incarnated, embodied in a particular Dasein, as the theologian seeks to understand and interpret the embodied experiences of others in the silent speaking of their language through the theologian's own embodiment in the silent speaking of her or his language. The task of doing theology in this first moment of the Christ-Ereignis is read together with the first two steps of the five dance movements, which is to listen ${ }^{10}$ and to interpret $^{11}$ (see Meylahn 2013:53 and Meylahn 2014a:5 of 11).

In this first step (incarnation), two world-creations come together and in that coming together there is a new worldcreation (poiesis): the world-creation of the theologian and the world-creation of the community and the new world-creation

10.Listening (double listening): 1 . Listen to the dominant common language of the particular context; 2 . 'Listen to the shadow stories that are suppressed, excluded, ignored and marginalised, but question the dominant common language of the particular context' (Meylahn 2014a:5 of 11).

11.Interpreting: 'The particular stories (texts) need to be read within their contexts. To read the various particular texts within their contexts can only be done with the help of other disciplines and thus this is an inter-disciplinary approach. Part of the the help of other disciplines and thus this is an inter-disciplinary approach. Part of the story of ultimate reference which binds (regilare) into a particular community. This story of ultimate reference which binds (regilare) into a particular community. This
sacred story (religion) needs to be read and interpreted' (Meylahn 2014a:5 of 11). of the fusion of horizons of these two. Each of these worldcreations or thought-worlds has a dominant myth or a sacred canopy that binds that whole thought-world together or that binds (religare) that world-creation into a comprehensible whole. These dominant myths that bind (religare) the worldcreation together can be interpreted as religion and therefore they are of special interest to the theologian. The theologian's task is to identify the religion/s or dominant myths (ultimate references) that allow these world-creations to appear as God-given or natural; that is, as absolute: as the way things are or should be. These dominant myths provide the ultimate legitimisation and norms to present the world-creation as reality. They provide the norms and rules for the particular ontology of the particular world, giving each thing its defined place and identity. Two dominant myths today could be seen as the market and in a certain sense science and technology as well.

This critical engagement with the dominant myths, discovering the gods of the contexts, is read together with the third movement: discernment ${ }^{12}$. Discernment has to do with discerning the powers that be, recognising the religion as the founding and legitimising myth of each of these worldcreations, and that binds (religare) this world together into a whole.

The focus is on discernment and not judgement, because on the basis of what would one judge the religions of these different world-creations? One could only judge the religions if one had a God's eye view, but that is impossible.

Therefore the critical discernment cannot be on the basis of having eaten of the tree of knowledge of good and evil and thus from a superior position to judge the various gods on the basis of some or other sacred text (historical theology) or sacred idea (systematic theology) or foundation. The discernment is not from a position of power or insight, but is based on a humble recognition that each context, even one's own context of critical discernment, has its gods (religion). This could be highly frustrating, and many people would interpret this as absolute relativism: where everything goes, as everything is equally valid. There are various thinkers who have tried to overcome this absolute relativism, for example Habermas (1996) who developed validity claims giving one the necessary tools to discern between various world-creations. Browning developed in conversation with Habermas such claims for theology (Browning 1991:71). In Church emerging from the cracks (Meylahn 2012) an alternative route to Browning, and thus Habermas, is followed. In keeping with the idea of imitatio Christi one follows Christ's bias for the least of the brothers and sisters, rather than trying to discern between world-creations on the basis of validity claims. This bias for the least of the brothers and sisters helps one to recognise the marginalised and ostracised and

12.Discerning: 'The sacred story needs to be discerned as ultimate myths or ideology, not judged from an outside (God's view), nor by comparing them to a higher authority or higher myth, but from within the intertextual context. These ultimate myths as totalising myths have many victims - marginalised and ostracised shadow stories (texts) that question the ultimate authority of these sacred texts' (Meylahn stories (texts) that 
become neighbour (see Meylahn 2009) to them within a particular Dasein of a particular world-creation. The task is to in each of the world-creation to first identity the dominant binding myths (religion) and then to seek out that which those dominant myths marginalise or ostracise: the shadow stories. The identification of shadow stories is obviously dependent on one's own view of the world, that is, one's own world-creation with its particular divinity: legitimising myth. A feminist liberation theologian would recognise the marginal voices of women first and a Marxist theologian would immediately recognise the shadow stories of the exploited workers, and their choice of shadow stories would be determined by their Marxist or feminist world-view with their respective divinities (founding myths). Therefore there is no' correct' choice of marginal voices, and marginal voices, as such, are not the salvation of that particular world. Each choice of marginal voice, shadow story, creates in its choice its own marginal voices, because with each choice there is exclusion. The particular marginal voices in themselves are not the answer, there will always be poor amongst you, Jesus says (Jn 12:8); rather, it is what association with marginal voices (becoming brother and sisters to those voices), and always again the new marginal voices, does to the particular world-creations.

The chosen marginal voices or shadow stories haunt, irritate, challenge and disturb the dominant myths as these shadows stories question the validity of the dominant myths. Shadow stories are stories that should not exist according to the dominant myth, and therefore these myths will try everything in their power to exclude these stories and/or marginalise them. The shadow stories challenge the ultimate legitimacy of the myth and therefore the myth will seek to get rid of that which seeks to question its authority. The very existence of the shadow stories (those that should not be) questions the dominant ontology of the world-creation. The shadow stories, being shadow stories do not always have the power to express themselves and therefore they need the theologian, imitating Christ, to associate with them. In that association their voicelessness receives a voice and can challenge the dominant myth. Now the voicesless, the shadow stories, those that do not exist, all of a sudden exist (become visible, audible) and in their visibility as nonexisting they challenge the existing norms thereby unbinding the binding (religare) force of the world-creation.

Christ's, and therefore the theologian's, becoming neighbour (see Meylahn 2009) to these shadow stories blasphemes (questions the authority) the dominant myths. The only way the dominant myths can respond to such a challenge is to destroy this ultimate criminal. He is an ultimate criminal because it is not just a matter of breaking a law or two, but it is questioning the very binding glue or legitimising force of the whole ontology, the whole system. The ultimate criminal challenges both the ontology as well as the founding myths (god/s). Jesus is the ultimate criminal, not because he breaks one or two Sabbath rules, but because he threatens the whole system by loving the un-loveable and accepting the unacceptable. This love for the un-loveable threatens to unbind their whole world. The crucifixion was the only possible response to this absolute challenge, which challenged to unbind the Jewish world-creation, as well the Roman world-creation (1 Cor 2:8). Christ's love and grace shown to the unacceptable and marginal challenged the dominant myth (their gods) and therefore he was a blasphemer, as one who challenged the founding and legitimising myths.

The incarnation was the blasphemy, or one could even say that the incarnation was the death of God (radical immanence). Then the cross would be the blasphemy of blasphemy, or the death of the death of God and thus the utter forsakenness. One could argue that God (the divine) died in the incarnation and that the crucifixion is the death of the death of God (see Meylahn 2013:316f.). The crucifixion could therefore be interpreted as the death of the certainty of atheism, which does not translate into theism, but utter uncertainty, of being utterly forsaken of any foundation, even the foundation of the way of Christ, and therefore the logos of Christ is crucified: Christology (see Meylahn 2013:316ff.). But in that crucifixion is the birth of the impossible possible: resurrected life (Meylahn 2014:6 of 11).

Theologians, in their imitatio Christi, following the movements of the Carmen Christi, open themselves seek out the marginal and shadow stories and thereby open themselves to being labelled blasphemers as they challenge, by their association with the least of the brothers and sisters, the dominant legitimising myth. This association with the shadow stories challenges, and by challenging, blasphemes the gods of the various world-creations. This fourth movement, of Church emerging from the cracks, is described as re-interpreting or re-authoring ${ }^{13}$ (poeisis or poetics of the kingdom). Reauthoring or poetics of the kingdom happens when the particular stories of the context are read in an inter-textual reading, a reading between the stories interpreted within their context and the story of the Christ-Ereignis, and in this reading witnessing how the shadow stories challenge the dominant myths. The theologian reads this challenge in light of Christ's incarnation, ministry and crucifixion. In this article the story of Jesus is interpreted as an exemplary narrative, or one could say as a figure, of that which happens in texts (deconstruction because of différance $-{ }^{14}$ see Meylahn 2013:310f.). One could maybe even say that the story of

13.Re-authoring (Poiesis): The movement of re-authoring already begins with the previous movement of discernment. This movement is the re-reading of the texts within their contexts in the light or inter-textual reading with the story of Christ, as the story of the world (Meylahn 2014a:6 of 11)

14.'Why can one translate the Christ-Ereignis into the post-metaphysical metaphor and imagination of différance? Has a new truth been found? Has the "correct" interpretation of Christ been found? No, I could not have done otherwise as the letter arrives at its destination. Can the West think beyond Athens and Jerusalem or will Athens and Jerusalem always be part of thinking from a Western perspective? The Bible and the writings of the Ancient Greeks are part of the West's context. They form part of the West's narrative resources and thus imaginings. Postmey form part metaphysics developed out of this fertile ground, and thus the imaginings of postmetaphysics are within the metaphors of both Athens and Jerusalem, amongst thers. There is no outside text and therefore there are no imaginations outside the texts of the West for somebody whose context is influenced by the West. Could have been otherwise - that these two inter-texts translate into each other? Perhaps, as the letter does and possibly does not arrive at its destination, as it is haunted by a Christology or différance' (Meylahn 2014a:6 of 11). 
Christ (Carmen Christi) is a science of thought, or a science of reading texts within contexts.

'Following Christ into the incarnation and crucifixion by becoming neighbour to the shadow stories, the public theologian witnesses the auto-deconstruction of the gods' (Meylahn 2014a:7 of 11). I use the word 'witnesses', as one cannot say that the theologian does the deconstruction. One cannot do deconstruction; it is not a method to be applied to things. On whose or what authority would one deconstruct something? One can destruct something on somebody's authority or your own authority, but not deconstruct. Deconstruction (auto-deconstruction) is something that happens within texts because of difference, and therefore the theologian can only be a witness to the auto-deconstruction that happens. The theologian does not do the Christ-Ereignis, but in following Christ to the shadow stories, the theologian witnesses the Christ-Ereignis (auto-deconstruction) of the dominant myths through incarnation, ministry and crucifixion. In the auto-deconstructed space, after the crucifixion, something new can arise: resurrection. The resurrection can be interpreted as a new community, which is liberated from the dominant norms that are legitimised by the dominant myths, and therefore a community where there is neither Jew nor Greek, man or woman, free or slave (G1 3:28) or any other categorisation that strictly defines ontological place to things within a particular world.

This new community is not the answer, because the moment it understands itself as the answer, it has created a new dominant myth with new shadow stories, and therefore in need of deconstruction. The moment the new community is conscious of itself as new community and thereby has the power to bind people together (into community), and once it has the power to provide people with a unifying identity, it has religion (religare). A self-conscious community will have formed its own authorising and legitimising myth, which excludes and creates shadow stories.

This reminds one of the last thoughts Nietzsche penned to his friend Georg, during the final stages of his illness, 'After you had discovered me, it was no trick to find me: the difficulty now is to lose me... (signed) The Crucified' (Heidegger 1968:53). Christ is a liberating saviour, who liberates communities from their gods, but the danger is that Christ himself becomes a god.

Therefore I suggest thinking about a Christological community as a community that can never be, a community that can never exist as such, but always is a community still to come: an eschatological community awaiting the coming (second coming). One can state this using traditional ideas of the protestant tradition: it is a community that is dependent on the gift (sola gratia) of the Christ-Ereignis (sola Christus) that is witnessed and received in faith (sola fide), through becoming neighbour to the shadow stories. By becoming neighbour to the shadow stories the dominant myths are challenged in that they are auto-deconstructed. This is not something that one does, but it is an inner-textual event (sola scriptura).

Such a community can never be, because to become neighbour to the ever new shadow stories, or to become neighbour to the ever new other, is to become neighbour to the enemy and to invite the enemy in. The challenge of the Christian is to love the enemies (Mt 5 or Jn 13), but loving enemies means to love those who can destroy you. It is to become neighbour to that which will destroy the community, as Carl Schmitt (1976) argues that the loss of enemies is the death of the political. The political is created (community is created) on the basis of exclusion. By becoming neighbour to the enemy one loses the enemy as enemy and therefore the loss of the political: the possibility of community. The Christ-Ereignis can therefore be interpreted as the death of the political, because no community can be formed in this continuous challenge to love enemies. The same can be said with regards to theory. The Christ-Ereignis is the death of theory (logos) as well, because any theory is continuously deconstructed by that which the theory excludes or does not say, and therefore it is the death of logos. But logos cannot die, just as is impossible for metaphysics to die, but it can be thought through and thus be wounded - always open to the future (see Laruelle 2003:181), and therefore a crucified logos (Meylahn 2014a:7 of 11).

The last movement from Church emerging from the cracks develops the idea of the community always to come, in that the community opens itself to embrace anew the shadow stories: embracing listening ${ }^{15}$. The new resurrected (liberated) community needs to be embraced, but very conscious that with the embrace new margins and therefore exclusions are created. In the margins and cracks of the resurrected community already the new shadow stories are waiting to be listened to. In this sense the new community never is, but is always to come as it is always listening to the shadow stories in its own attempts at creating or being community. The new community can never be, but is always to come, and thus it is a community that is continuously reforming (ecclesia reformata). This continuous reformation is not driven by human will or power, but by what is happening in the texts of the community where the church or the theologians find themselves (verbum Dei).

\section{Christology: A holly folly or disruptive mutiny from the margins beyond good and evil and infinite demand}

I would like to propose a working description for theology as public Christology. Public Theology

is to witness in love, to bear testimony in faith and to receive the

Christ-Ereignis in grace as an inner and inter-textual event in reading

15.Embracing - listening: a dance without end in the time that remains: New lifegiving words are poetically formed and unique outcomes are discovered that can be embraced. These unique outcomes are not the final story, but they need to be listened to, discerned and re-authored in the time that remains (Meylahn 2014a:7 of 11). 
texts within their contexts and embracing the space of hope that such double reading creates to continue reading in the time that remains. (Meylahn 2014a:7 of 11)

This proposed working description can be described as a way of doing theology, or as a way of reading texts within context, in the sense of being a kind of methodology.

The words, 'doing', 'a way' or 'method' are too strong, as these words remind one of a praxis (theory-laden practice), in other words, a praxis that functions on the basis of certain foundational knowledge (theory) which guides and determines the way (practice). Edmund Arens developed the concept of Christopraxis (Arens 1992), which he developed in conversation with Habermas' (1996) communicative action. Again the idea of Christo-praxis is too strong, as it is guided by a theory of communicative action.

Instead of a way, what is being proposed here is more a Gelassenheit or spirituality of love. Love for enemy with an expectant hope to witness the Christ-Ereignis, which disclosingly appropriates a new community, but without disclosing anything and without being able to appropriate anything but hope, faith, grace and Christ, in text, through love alone. It can be described as a spiritual reading with a particular hermeneutic of love for marginal shadow stories. This hermeneutic of love for marginal stories is not founded on theory or orthodoxy or orthopraxis, but is inspired by hope, hoping to witness the Christ-Ereignis, and through faith to give testimony to that Ereignis in an inner- and intertextual reading, an inter-textual reading where the ChristEreignis (Carmen Christi) is read as a figure of the autodeconstruction that happens in texts when and where one finds oneself neighbour to the marginal and shadow stories of those texts. This inter-textual reading is a theo-poetics ${ }^{16}$, or rather a Christo-poetics, or even poetics of the kingdom, where what happens in texts is interpreted through the figure of the Christ-Ereignis so that one can witness and give testimony to this Ereignis as Christo-poetics. Christo-poetics is a poiesis of a new creation of the resurrection through the crucifixion (deconstruction). Yet, this new creation is not something stable and foundational, but if anything, a temporary vulnerable creation in a permanent state of being crucified and rising (simul Justus et peccator). The new community is a Christo-poetics that is vulnerable and wounded, like the lamb that was slain that enters the throne room to unlock the seven seals of history ( $\operatorname{Rv} 5: 6)$.

This spirituality or Gelassenheit is a reading of texts where one finds oneself neighbour to the shadow stories. In finding oneself neighbour to these stories one witnesses the blasphemy of the dominant myths, and therefore the crucifixion. One is interpreting this happening (in reading of

16.'What is important for theo-poetics and which prevents it from becoming theopoetry and eventually theo-politcs is that theo-poetics does not have an author there is no conclusive meaning, there is no order, but always complexity, and there is no cond, but openness to whe Thus, although theo-poetics is a kind of social construction (a poiesis), there is an important difference in the four characteristics of theo-poetics: no author, no conclusive meaning, no order but complexity, and no end but openness to what is still to come' (Meylahn 2014a:7 of 11). texts) through a Christo-poetics by an inter-textual reading of the Christ-Ereignis with the auto-deconstruction that happens in all texts. What happens in all texts is an auto-deconstruction because of différance or because of the future always to come. Such a reading can only ever offer a temporary vulnerable poiesis, yet in its temporary vulnerability it is also a fragile universalism, as it is a witnessing of auto-deconstruction as something that happens in all texts because of différance. As this is a possible spirituality of reading of all texts it can be seen as a public spirituality. It is a spiritual reading (Christ-poetical reading) of: public texts, academic texts, and of church texts of the various denominational traditions. A Christology is a spiritual sense of not-being ${ }^{17}$ because of love's call to become neighbour to the marginal voices in reading the texts in all three of Tracy's (1981:3-31) publics: academia, public and church. The theologian becomes neighbour to the marginal voices and therefore shares the non-being status of the marginal voices to reduce to nothing the dominant discourses of these three publics. The theologian by engaging the texts of these publics with a love for what is not said becomes neighbour to those marginal voices in the dominant discourses with a sense of expectancy (hope) for the ChristEreignis.

Therefore one can argue that Christology is never at home in any of these publics. As it is spirituality of non-being it does not have a home, just as the son of man does not have a place to lay his head (Matthew 8:20). Christology, being homeless, it does not have a home or a place, but it knocks on the doors and seeks hospitality and therefore is disruptive in the three publics. It is not a logos and thus, but if it is anything, it can only be a folly (1 Cor 1:27) to put to shame the wisdom of the world - the wisdom that binds (religare) these publics into an identifiable entity. But it is not a folly as understood in the tradition of morosophia (see Phan 2001 and Meylahn 2013:325ff.), as such a tradition would again be a construction, but, if anything, rather in the sense of the salos (Byzantine Holy Fools of late antiquity and early Middle Ages) whose openness to the Other allowed their continuous self-deconstruction (see Meylahn 2013:331). Yet, its fragile universal practicality cannot be denied in all three publics, because by becoming neighbour to the marginal and shadow stories, thereby witnessing the auto-deconstruction of dominant societal, academic and church discourses, who are thereby opened up for democracy and justice always still to come (see Derrida concerning justice and democracy to come - Derrida 2005:78-94).

Thus, by being a spirituality of non-being it has no home. Its homelessness and folly does not mean that it has no impact on the various homes or discourse as it plays an important role in the various discourses by knocking on their doors it opens these discourses up for the future still to come and in that sense it is a

17. There are enough references throughout the New Testament for the call to nonbeing of the Christian. There is the call to be in the world, but not of the world (John 17:14-15) as well as the call not to conform to the patterns of the world (John 17:14-15) as well as the call not to conform to the patterns of the world Romans 12:2). In 1 Corinthians 1:28 God's choice of those that are not to reduce to nothing things that are echoes - something of the call to auto-deconstruction through becoming neighbour to those who are not so as to reduce to nothing those that are (the dominant discourses). Even more radical are Jesus' calls to become nothing (death) for the other as a call to discipleship, John 15:13. In Matthew 16:24 there is the call to deny yourself and pick up the cross to become disciple' (Meylahn 2014a:8 of 11). 
discourse of the future - future being its only home: the kingdom to come. (Meylahn 2014a:11 of 11)

\section{Acknowledgements Competing interests}

The author declares that he has no financial or personal relationships which may have inappropriately influenced him in writing this article.

\section{References}

Arens, E., 1992, Christopraxis: Grundzuge theologischer Handlungstheorie, Herder, Freiburg.

Brassier, R., 2001, 'Alien Theory: The decline of materialism in the name of matter', $\mathrm{PhD}$ thesis, Dept. of Philosophy, University of Warwick.

Brassier, R., 2003, 'Axiomatic Heresy: The non-philosophy of François Laruelle', Radical Philosophy 121, 24-35.

Browning, D.S., 1991, A Fundamental practical theology: Descriptive and strategic proposals, Fortress Press, Minneapolis, MN.

Caputo, J.D., 2006, The weakness of God: A theology of the event, Indiana University Press, Indianapolis, MN.

Derrida, J., 1995, 'Sauf le nom', in J. Derrida \& T. Dutoit (ed.), On the name, transl. D. Wood, J.J. Leavey \& I. McLeod, pp. 35-88, Stanford University Press, Stanford.

Derrida, J., 1997, Of grammatology, transl. G.C. Spivak, John Hopkins Press, Baltimore,

Derrida, J., 2002, "Faith and knowledge: The two sources of "religion" at the limits of reason alone', in G. Anidjar (ed.), Acts of Religion, transl. J.F. Graham, pp. 40-101, Routledge, London

Derrida, J., 2005, 'The last of the rogue states: The "democracy to come," opening in two turns', transl. R-A Brault and M. Naas (eds.), Rogues: Two essays on reason, pp. 78-94, Stanford University Press, Stanford.

Derrida, J., 2008, 'How to avoid speaking: Denials', in P. Kamuf \& E. Rottenberg (eds.) Psyche: Inventions of the Other, transl. K. Frieden \& E. Rottenberg, vol. II, pp. 143195, Stanford University Press, Stanford, CA

Ebeling, G., 1975, Studium der Theologie: Eine enzyklopädische Orientierung, JCB Mohr, Tübingen.

Habermas, J., 1996, 'What is universal pragmatics?' in W. Outhwaite (eds.), The Habermas reader, pp. 118-131, Polity Press, Cambridge.

Heidegger, M., 1968, What is called thinking? transl. F.D. Wieck \& J.G. Gray, Harper \& Row Publishers, London.
Heidegger, M., 1971, Poetry, language, thought, transl. A. Hofstadter, Harper \& Row, New York, NY.

Hofstadter, A., 1971, 'Introduction', in M. Heidegger (eds.), Poetry. Language, thought, pp. ix-xxii, Harper \& Row, New York, NY.

Kearney, R., 2001, The God who may be: A hermeneutics of religion, Indiana University Press, Bloomington, IN.

Kearney, R 2010, Anatheism: Returning to God after God, Columbia University Press, New York, NY.

Laruelle, F., 1999, 'A summary of non-philosophy', Pli: The Warwick Journal of Philosophy 8, 138-148.

Laruelle, F., 2003, 'What can non-philosophy do?', transl. R Brassier, Angelaki: Journal of the Theoretical Humanities 8(2), 169-189.

Laruelle, F., 2008, 'A Science of Christ', paper presented at the Grandeur of Reason: Religion, tradition and universalism conference in Rome, 01-04 September.

Laruelle, F., 2010, Philosophies of difference: A critical introduction to non-philosophy, transl. R. Gangle, Continuum, New York NY. (Kindle edn.).

Luther, M., 1518, 'The Heidelberg Disputation', in The book of concord: Confessions of the Lutheran Church, bookofconcord.org viewed 31 August 2011, from http:// bookofconcord.org/heidelberg.php

Meylahn, J.-A., 2009, 'Responsibility, God and society: The cry of the other in the sacred texts as a challenge towards responsible global citizenship', HTS Teologiese Studies/Theological Studies 65(1), 5. http://dx.doi.org/10.4102/hts. v65i1.131

Meylahn, J.A., 2012, Church emerging from the cracks: A church in, but not of the world, Sun Media, Bloemfontein.

Meylahn, J.-A., 2013, The limits and possibilities of postmetaphysical God-talk: A conversation between Heidegger, Levinas and Derrida, Peeters, Leuven. (Studies in Philosophical Theology 52).

Meylahn, J.-A., 2014a, 'Postfoundational practical theology as public Christology', Julian Müller Festschrift, Verbum et Ecclesia 35(2), 11. http://dx.doi.org/10.4102/ ve.v35i2.875

Meylahn, J.-A., 2014b, The local South African worshipping community as a site for spiritual formation towards transformation, Verbum et Ecclesia 35(3), Art. \#1340, 6 pages. http://dx.doi.org/10.4102/ve.v35i3.1340

Phan, P.C., 2001, 'The wisdom of holy fools in postmodernity', Theological Studies 62, 730-752.

Schmitt, C 1976, The concept of the political, transl. G. Schwab, Rutgers University Press, New Brunswick.

Tracy, D., 1981, The analogical imagination, Crossroad, New York, NY.

Ricoeur, P., 1973, 'The model of the text: Meaningful action considered as a text', New Literary History - 'What Is Literature?', 5(1), 91-117.

Van den Hoogen, T., 2013, 'Spirituality of foundational theology' Academic table discussion at the university of Pretoria, 06.06.2013 by Prof. dr. Toine van den Hoogen of the Theology Faculty of Njmegen, Netherlands. 